\title{
Landscape-level gene flow in Lobaria pulmonaria, an epiphytic lichen
}

Post-print/Accepted manuscript

Silke Werth

Felix Gugerli

Rolf Holderegger

Helene H. Wagner

Daniela Csencsics

Christoph Scheidegger

WERTH, S., GUGERLI, F., HOLDEREGGER, R., WAGNER, H. H., CSENCSICS, D. and SCHEIDEGGER, C. (2007), Landscape-level gene flow in Lobaria pulmonaria, an epiphytic lichen. Molecular Ecology, 16: 2807-2815. doi:10.1111/j.1365-294X.2007.03344.x

This is the peer reviewed version of the following article: WERTH, S., GUGERLI, F., HOLDEREGGER, R., WAGNER, H. H., CSENCSICS, D. and SCHEIDEGGER, C. (2007), Landscape-level gene flow in Lobaria pulmonaria, an epiphytic lichen. Molecular Ecology, 16: 2807-2815, which has been published in doi:10.1111/j.1365-294X.2007.03344.x This article may be used for non-commercial purposes in accordance with Wiley Terms and Conditions for Self-Archiving.

\section{HOW TO CITE TSPACE ITEMS}

Always cite the published version, so the author(s) will receive recognition through services that track citation counts, e.g. Scopus. If you need to cite the page number of the TSpace version (original manuscript or accepted manuscript) because you cannot access the published version, then cite the TSpace version in addition to the published version using the permanent URI (handle) found on the record page. 
1. Title: Landscape-level gene flow in Lobaria pulmonaria, an epiphytic lichen

2. Authors: Silke Werth, Felix Gugerli, Rolf Holderegger, Helene H. Wagner, Daniela Csencsics and Christoph Scheidegger

5

3. Author affiliation: WSL Swiss Federal Research Institute, Zürcherstrasse 111, CH-8903

Birmensdorf, Switzerland.

4. Keywords: Genetic discontinuity, barrier, lichenized ascomycetes, genetic structure

10

5. Corresponding author: Silke Werth, UCLA, Department of Ecology and Evolutionary Biology,

Warren Hall, 900 Veteran Avenue, Los Angeles, California 90024, United States. Fax: ++1-(310)-7941431.Email: werth@ucla.edu

15 6. Running head: Landscape-level gene flow in Lobaria

7. Word count: 5497 


\begin{abstract}
Epiphytes are strongly affected by the population dynamics of their host trees. Owing to the spatio-temporal dynamics of host tree populations, substantial dispersal rates - corresponding to high 25 levels of gene flow - are needed for populations to persist in a landscape. However, several epiphytic lichens have been suggested to be dispersal-limited, which leads to the expectation of low gene flow at the landscape scale. Here we study landscape-level genetic structure and gene flow of a putatively dispersal-limited epiphytic lichen, Lobaria pulmonaria. The genetic structure of L. pulmonaria was quantified at three hierarchical levels, based on 923 thalli collected from 41 plots situated within a 30 pasture-woodland landscape and genotyped at six fungal microsatellite loci. We found significant isolation by distance, and significant genetic differentiation both among sampling plots and among trees. Landscape configuration, i.e., the effect of a large open area separating two forested regions, did not leave a traceable pattern in genetic structure, as assessed with partial Mantel tests and analysis of molecular variance. Gene pools were spatially intermingled in the pasture-woodland landscape, as 35 determined by Bayesian analysis of population structure. Evidence for local gene flow was found only in a disturbed area that was mainly colonised from nearby sources. Our analyses indicated high rates of gene flow of L. pulmonaria among forest patches, which may reflect the historical connectedness of the landscape through gene movement. These results support the conclusion that dispersal in L. pulmonaria is rather effective, but not spatially unrestricted.
\end{abstract}




\section{Introduction}

Migration among spatially segregated habitat patches is a key process in metapopulations (Hanski, Gaggiotti, 2004; Levins, 1969). High migration rates are necessary for persistence of organisms that depend on habitat patches prone to rapid turnover in order to maintain metapopulations and to keep up with the spatio-temporal dynamics of their habitat. Epiphytic lichens and bryophytes that colonise mature forest trees generally exhibit migration characteristics of such patch-tracking metapopulations (Johansson, Ehrlén, 2003; Snäll et al., 2004; Snäll et al., 2003), with the epiphytes' population dynamics being constrained by the dynamics of the host tree population (Snäll et al., 2005; Wagner et al., 2006).

For epiphytes associated with low-density or patchily distributed host trees, distances among habitat patches (i.e. individuals or groups of host trees) can be long, and the total amount of suitable habitat in a landscape may be low. Host trees need to reach a minimum age before their bark becomes a suitable habitat for epiphytes, but such suitable habitat patches disappear when host trees die or are harvested. As a consequence, there is only a limited time period between patch colonisation by an epiphyte and its local extinction. Because diaspores of most epiphytic bryophytes, lichens, ferns, and orchids are small and wind-dispersed (Bailey, 1976; Barkman, 1958; Galloway, Aptroot, 1995; Snäll et al., 2004), epiphytes have been expected to be good passive dispersers and to exhibit high rates of migration among host trees and/or local populations across a landscape. This should result in high levels of gene flow and, thereby, low levels of genetic differentiation.

In epiphytes specialised on rare or spatially scattered host tree species, long-distance dispersal is required for successful colonisation of new habitat patches. Based on this latter reasoning, a limited dispersal ability would be a hindrance for the colonisation of, e.g., young forests by old-forest associated epiphytes (Dettki et al., 2000; Hilmo, 2002; Sillett et al., 2000). Experimentally determined dispersal distances of epiphytic lichens are indeed low, in the range of tens of meters (Armstrong, 1987; Armstrong, 1994; Walser et al., 2001) or a few hundred meters (Werth et al. 2006a). Such a limited dispersal ability coupled with long distances among suitable habitat patches would imply low rates of gene flow among and substantial genetic isolation of populations of epiphytes. As a consequence, high genetic differentiation is expected among populations for epiphytes with limited dispersal ability.

Population genetic investigations of epiphytes within patchily forested landscapes may reveal which of the above two scenarios holds true: low effective dispersal and gene flow with substantial genetic differentiation or high dispersal and gene flow paralleled by low genetic differentiation. In the first scenario, isolation by distance effects and a spatial aggregation of individuals originating from the same local gene pool are expected, while the second scenario would result in weak isolation by distance, and a random recruitment of individuals from a common gene pool across a landscape.

80 Discriminating between the two scenarios is of interest both as a test of theoretical predictions of metapopulation dynamics as well as for conservation practice since a large number of epiphytic lichens are endangered by habitat fragmentation and change (Lidén et al., 2004; Radies, Coxson, 2004; Scheidegger, Goward, 2002; Thor, 1998; Tønsberg et al., 1996; Wirth, 1999). For instance, if gene flow and dispersal of a given species is restricted to short distances, i.e. among groups of host trees, conservation strategies should aim at increasing the amount of suitable habitat and connecting spatially discrete epiphyte populations (Öckinger et al., 2005). But even in continuous forests, natural 
disturbances or human forest management may endanger the long-term persistence of dispersal-limited epiphytes if the host tree population dynamics is faster than the patch-tracking population dynamics of epiphytes.

Our model species was Lobaria pulmonaria (L.) Hoffm., which is a foliose epiphytic lichen considered to be endangered in several European countries (Scheidegger et al., 2002; Søchting, Alstrup, 2002; Wirth et al., 1996). It is associated with old-growth forests and pasture-woodland landscapes (Rolstad et al., 2001; Rose, 1992), and has been suggested to be dispersal-limited (Öckinger et al. 2005). L. pulmonaria forms both vegetative and sexual propagules (Yoshimura, 1971) at an age of more than 25 years (Scheidegger, Walser, 1998). Dispersal by vegetative propagules has been suggested as the predominant dispersal mode in L. pulmonaria (Wagner et al., 2005; Wagner et al., 2006; Walser, 2004; Werth et al., 2006b).

In this study, we investigated gene flow in L. pulmonaria in a pasture-woodland landscape. The composition of this landscape, i.e. old forests managed with uneven-aged forestry, fire-disturbed young forests, few intensively logged forests and large wooded pastures (Kalwij et al., 2005), allowed us to investigate the genetic variation of local $L$. pulmonaria populations differing in age and population history as well as in their degree of spatial isolation. We quantified gene flow among local populations of L. pulmonaria within the pasture-woodland landscape. We also assessed whether the spatial arrangement of the different types of landscape elements influenced genetic structure in the lichen. Specifically, we tested the hypothesis that gene flow among populations of the forest-dwelling lichen L. pulmonaria is restricted, leading to genetic differentiation as a result of isolation.

\section{Methods}

\section{Study area}

Our study area was situated in the northern part of the Parc Jurassien Vaudois in the Jura Mountains in western Switzerland with a spatial extent of $46^{\circ} 28^{\prime}-34^{\prime} \mathrm{N}$ and $06^{\circ} 06^{\prime}-16^{\prime} \mathrm{E}$ and an elevation of $1300-1450 \mathrm{~m}$. The study landscape represents a typical pasture-woodland landscape

115 composed of Norway spruce forests (Picea abies) and wooded pastures on limestone bedrock. Mean annual precipitation and mean July temperature are about $2100 \mathrm{~mm}$ and $10^{\circ} \mathrm{C}$, respectively (Kirchhofer, 1995). The host trees of L. pulmonaria in the study area were sycamore maple (Acer pseudoplatanus) and beech (Fagus sylvatica), which were both scattered in forested areas (Kalwij et al., 2005), but only rarely found on wooded pastures.

In our study area, two large forested areas ('regions') were separated by a large open area about $1 \mathrm{~km}$ wide (Fig. 1). While the western and eastern parts of this open area represent large wooded pastures, the central part of the open area, about $200 \mathrm{~m}$ wide and $1 \mathrm{~km}$ long, is currently covered by herbaceous mire vegetation (see Sjögren, 2006, for a map of the mire and adjacent wooded pastures).

125 Peat sediments from this mire have been used to reconstruct vegetation history, and the peat record dates back until 3400 BP (Sjögren, 2006). 


\section{Sampling}

Our study plots are a subsample taken from a total of 251 randomly sampled plots of a previous study (Kalwij et al., 2005). Plots containing L. pulmonaria were selected in the two forests

130 west and east of the wooded pasture in approximately equal sampling density and ensuring to cover a range of local population sizes. A hierarchical random sample of 923 thalli was collected from 41 plots of 1 ha. Within each plot, all potential host trees of L. pulmonaria were searched for L. pulmonaria, and at least 20 samples were collected per plot. If fewer than 20 trees were colonised by L. pulmonaria, which was the case in 36 out of 41 plots, multiple thalli were sampled per tree, sampling an equal 135 number of thalli from all colonised trees. If fewer than 20 thalli were present in a plot, every thallus found was included (for a detailed overview of the samples collected in each plot, see Table 1).

\section{Molecular analysis}

Total DNA was isolated from cleaned and lyophilised lobe tips of L. pulmonaria using the DNeasy 96 plant kit (Qiagen) according to the manufacturer's protocol. Six unlinked, fungal-specific

140 microsatellite loci, LPu03, LPu09, LPu15, LPu16, LPu20, and LPu27 (Walser et al., 2004), were electrophoresed using an ABI 3100-avant automated DNA sequencer (Applied Biosystems) and assigned base pair sizes using GENOTYPER version 2.1 software based on ROX 500 molecular weight marker (Applied Biosystems). A full description of the methods is given in Werth et al. (2006b).

\section{Statistical analysis}

145 We tested the selective neutrality of the set of microsatellite markers using the EwensWatterson test for neutrality (Manly, 1985) as implemented in POPGENE version 1.32 (Yeh, Boyle, 1997).

To test for isolation by distance (Wright, 1943) in the haploid fungus, we performed a Mantel permutation test with 1000 permutations (Mantel, 1967) of geographic distance between thalli and shared allele distance using the library VEGAN version 1.6-7 (mantel, Dixon, 2003; Oksanen, 2005) in R ( $\mathrm{R}$ Development Core Team, 2004). Shared allele distances between individuals, a distance measure based on the Infinite Alleles Model, were calculated by using the library APE version 1.4 (dist.gene, Paradis et al., 2004) in R. The Mantel statistic, $r_{\mathrm{M}}$, quantifies the correlation between genetic and geographic distance.

To partition molecular variance at different hierarchical levels, we performed analyses of molecular variance (AMOVA) using 1-ha plots nested within regions and trees nested within plots using the F-statistics approach in ARLEQUIN version 3.11 (Excoffier et al., 2005). Trees from which only one 160 sample was available were excluded from tree-level AMOVA, excluding 153 of a total of 923 thalli. Four plots from which only a single sample had been collected per tree, were excluded from the plotlevel AMOVA (W139, W151, W185, W202; 93 samples removed).

For the purpose of assigning L. pulmonaria thalli to populations, identifying recent migrants, and inferring the number of gene pools across the landscape, a Bayesian analysis of population structure was run as implemented in STRUCTURE version 2.1 (Pritchard et al., 2000). Here, individual multilocus genotypes are probabilistically assigned to a user-defined number $(K)$ of randomly mating demes assumed to be in gametic equilibrium (i.e., gene pools). We ran three replicate simulations for 
each $K \in\{1, \ldots, 40\}$, and, after a burn-in period of $10^{5}$ iterations, $10^{6}$ iterations were run in order to sample the posterior distribution. An admixture model was used in which the fraction of ancestry from each gene pool is estimated for each sampled individual. The prior of individual admixture, alpha, was assumed to be uniform for all gene pools. Panmictic gene pool allele frequencies were assumed independent of each other (Falush et al., 2003). Individuals of over $80 \%$ probability of ancestry in a given gene pool were regarded as "assigned" to this gene pool, whereas all other individuals were

175 classified as "unassigned". We inferred the number of gene pools using the methods given in Evanno et al. (2005). The statistic $\Delta K$ was calculated, which is based on the rate of change in the log likelihood of the data between successive $K$ values. The true number of gene pools is determined as the modal value of the distribution of $\Delta K$ over $K$ (Evanno et al., 2005).

We attempted to determine whether the spatial configuration of landscape elements influenced population structure in L. pulmonaria, and if genetic discontinuities were found in the landscape which were related to landscape elements potentially acting as barriers to gene flow. First, we performed a partial Mantel permutation test (Oksanen, 2005) that allowed us to assess whether gene flow was higher within continuous forests than across a large wooded pasture. In the partial Mantel test, the first matrix was comprised of pairwise allele-sharing distances between thalli ("genetic distance"). The second matrix ("landscape configuration") was a binary matrix with entries of one if L. pulmonaria thalli spatially separated by the wooded pasture were compared with each other. All other entries, i.e. thalli separated by continuous forest, were coded with zero. The third matrix consisted of Euclidean geographic distances among thalli ("geographic distance"). The partial mantle statistic, $r_{\mathrm{M}}$, estimates

190 the correlation between the first two matrices (genetic distance, landscape configuration) while controlling for the effect of the third matrix (geographic distance) (Legendre, Legendre, 1998). This procedure allows assessing the effect of landscape configuration disentangled from a mere effect of geographic distance (i.e., isolation by distance). Second, for a posteriori detection of boundaries to gene flow in the study landscape, we used the Monmonier algorithm (Monmonier, 1973) implemented in BARRIER version 2.2 (Manni et al., 2004). As input coordinates, we used the central coordinates of each 1 ha sampling plot. We did not delete any edges of the original triangulation created by the software. To create barriers, pairwise $F_{\mathrm{ST}}$ values, calculated from the coancestry coefficient $\theta$ (Reynolds et al., 1983) as $-\ln (1-\theta)$, were calculated with 100 bootstrap matrices in MICROSAT version 1.5 (Minch, 2001). We calculated three barriers for each of the 100 bootstrapped matrices.

\section{Results}

The six microsatellite loci employed did not deviate significantly from the expectation of selective neutrality, as evidenced by the fact that the observed $F$-value was very similar to the average of the simulated $F$-statistics and lay within the $95 \%$ confidence interval of the simulated values for all

205 loci (Table 2). The set of six microsatellite loci employed in this study is thus appropriate for characterising neutral genetic variation. We found significant, but weak, isolation by distance in Lobaria pulmonaria from the studied Swiss pasture-woodland landscape (Mantel permutation test, $r_{M}=0.154, p<0.001$ ). The analysis of molecular variance (AMOVA) showed that most of the molecular variance was found among plots within regions, and among trees within plots, while molecular variance among regions explained a small and non-significant amount of the total variance (Table 3). 
A Bayesian analysis of population structure was performed to assign L. pulmonaria thalli to populations, identify recent migrants, and infer the number of gene pools in the study landscape. The number of gene pools inferred with from the method by Evanno et al. (2005) was five, and the five

215 gene pools were spatially intermingled (Fig. 1). Also, for no obvious reason less individuals were assigned to populations in the eastern part of the study area.

To investigate the effect of landscape configuration on gene flow in L. pulmonaria, we performed a partial Mantel test and used the Monmonier algorithm to detect genetic discontinuiuties in 220 the landscape. We found no correlation between landscape configuration and genetic distance of $L$. pulmonaria (partial Mantel permutation test, $r_{M}=-0.09946 ; p=1.0$ ). Thus, genetic distances among $L$. pulmonaria thalli separated by wooded pasture were not significantly different from those among thalli separated by continuous forest, which implies that gene flow across the wooded pasture was as efficient as across continuous forest. Using the Monmonier algorithm (Manni et al., 2004), we found genetic discontinuities in the landscape with high bootstrap support (Fig. 2), separating three plots in the northwestern part of the study area from neighbouring plots.

\section{Discussion}

The aim of our study was to quantify landscape-level gene flow among populations of $L$. pulmonaria. Specifically, we tested the hypothesis of significant genetic differentiation at three 230 hierarchical levels in L. pulmonaria - among forested regions, among plots, and among trees. If significant genetic differentiation were found, it would indicate restricted gene flow at a respective spatial scale. Secondly, we also assessed if landscape configuration influenced the genetic structure of L. pulmonaria.

We found significant genetic differentiation in Lobaria pulmonaria both among plots and among trees, indicating restricted gene flow at these hierarchical levels (Table 3). The overall measures of genetic differentiation, were highly significant at both hierarchical levels $\left(\Phi_{\mathrm{ST}}=0.462\right.$ and 0.817 at the plot and tree level, respectively); these are very high values of genetic differentiation. We also found significant differentiation among lichens collected from different host trees within plots. A few 240 other studies have also found genetic differentiation among lichen populations. For instance, Lindblom and Ekman (2006) investigated populations of the lichen Xanthoria parietina in a landscape of a comparable spatial extent as that of our study, with a maximum distance among populations of about $3.7 \mathrm{~km}$. They observed significant overall $\Phi_{\mathrm{ST}}$ values of 0.199 and 0.203 for DNA sequence data of IGS and ITS, two non-coding regions within the nuclear ribosomal gene cluster. The appropriate scale of 245 comparison with our data is the plot level (see above), and our corresponding $\Phi_{\mathrm{ST}}$ value was about twice as high as that of $X$. parietina. In contrast, in the terricolous lichen Cladonia arbuscula, no significant population subdivision was found $\left(\Phi_{\mathrm{ST}}=0.019\right)$ when a $2 \mathrm{~km}$ range was investigated, which is partly explained by the comparatively low sample size (Robertson, Piercey-Normore, 2007). It is striking, however, that the overall genetic differentiation among populations of Cladonia arbuscula 250 was 10 and 24 times lower than in X. parietina and L. pulmonaria, respectively. Similarly, no significant genetic differentiation $\left(\Phi_{\mathrm{ST}}=0.007\right)$ was found among populations of the epiphytic lichen Ramalina menziesii collected across a range of $2 \mathrm{~km}$ from an oak-savanna landscape situated in southern California (Werth, Sork, submitted). It is hard to come to general conclusions on gene flow in lichens when looking at the above examples. Lobaria pulmonaria and X. parietina show high genetic differentiation despite of the fact that they exhibit a dispersal syndrome (ascospores in X. parietina; 
ascospores and small vegetative propagules in L. pulmonaria) that should potentially enable them to disperse better than the species for which low differentiation was found, which are both thought to disperse mainly with comparative large and heavy thallus fragments. More studies are needed to understand the relationship between the dispersal syndrome of lichens and its consequences on genetic structure.

Second, we found significant, but weak, isolation by distance in the L. pulmonaria population, a result which is consistent with restricted gene flow at the local scale. Isolation by distance is a process by which geographically restricted gene flow creates genetic structure, even in continuous populations (Hardy, Vekemans, 1999; Slatkin, 1993). The present weak isolation by distance was also in accordance with our analyses of molecular variance (see above) and the Bayesian analysis of population structure. Our finding of weak isolation by distance (Wright, 1943) is corroborated by geostatistical methods such as variograms performed on a subset of our data, or the whole data set, respectively (Wagner et al., 2005; Werth et al., 2006b). It is astonishing that we found isolation by distance despite the fact that the spatial scale observed was comparatively small, i.e., within a landscape of about $9 \mathrm{~km}^{2}$. Perhaps less surprisingly, isolation by distance was found on a regional scale in populations of $L$. pulmonaria $(=500 \mathrm{~km}$, Walser et al., 2005).

Significant genetic discontinuities were found that separated three genetically almost uniform sampling plots in the northwest of the study area from neighbouring plots (Fig. 2). This pattern is most likely to have arisen from local dispersal and recruitment of L. pulmonaria in the north-western part of the study area that was affected by stand-replacing disturbance 131 years ago (Kalwij et al., 2005). Otherwise, the genetic structure of L. pulmonaria did not appear to be affected by the spatial arrangement of different types of landscape elements - we found no effects of landscape configuration: (1.) There was no significant molecular variance in Lobaria pulmonaria attributable to two forested regions separated by a large open area (AMOVA, $\Phi_{\mathrm{CT}}=0.000^{\mathrm{ns}}$, see Table 3). (2.) The result of the partial Mantel test indicated that landscape configuration did not account for the observed genetic structure. (3.) Monmonier's (1973) algorithm to detect genetic boundaries did not identify a relevant genetic discontinuity between the forested regions (Fig. 2). (4) The Bayesian analysis of population structure indicated that five gene pools were present in the landscape of we studied, but these gene pools were spatially intermingled and their geographic distribution did not reflect the landscape configuration (Fig. 2 ). This finding seems to reflect the dynamic nature of $L$. pulmonaria populations and the historical connectedness of the landscape. Indeed, most populations investigated were admixed, with the notable 290 exception of populations that had been disturbed 131 years ago (Kalwij et al., 2005; Werth et al., $2006 b)$, situated in the north-western part of the study area.

Palaeoecological investigations demonstrated that spruce forest with scattered deciduous trees persisted since 5000 years in our study area in the Swiss Jura Mountains (Mitchell et al., 2001); thus, 295 the L. pulmonaria population we investigated may be very old. The low genetic differentiation observed among forested regions (Table 3) indicated that the L. pulmonaria populations separated by the large open area may have been historically connected by gene flow. From this large open area, currently only one tree colonised by L. pulmonaria ('stepping stone') is known, located in the vicinity of the large forest in the West of our study area (S. Werth, unpublished data). Taking into consideration that the studied landscape is a dynamic pasture-woodland, the spatial extent of the open area may have 
varied considerably over time, giving rise to a varying number of stepping stone populations which may formerly have connected the two continuously forested regions we investigated. The amount of deciduous trees and, thus, the availability of suitable host trees for L. pulmonaria has decreased considerably during the last two millennia (Mitchell et al., 2001; Sjögren, 2006), making the latter 305 scenario very likely. Also, the forest regions may not have been isolated sufficiently long enough to observe an effect of the landscape configuration today.

Overall, we found that gene movement in Lobaria pulmonaria was spatially restricted, and one might argue that this reflects spatially restricted dispersal of diaspores in L. pulmonaria (i.e., 310 'dispersal limitation'). However, the hypothesis of high mortality of dispersed diaspores and of juveniles leads to the same expected genetic structure as dispersal limitation. Werth et al. (2006a) found a high amount of vegetative and/or sexual diaspores dispersed over large distances in Lobaria pulmonaria. Therefore, dispersal limitation does not seem the most important mechanism underlying the high genetic differentiation observed among populations of L. pulmonaria in our study area. There

315 are at least other processes that may lead to the high genetic differentiation we observed: photobiont limitation and establishment limitation.

First, in the case of dispersed ascospores, the absence of appropriate photobiont partners (green algae and cyanobacteria in L. pulmonaria) prevents the establishment of thalli from spores.

320 Strong fungal specificity in photobiont choice has indeed been documented in other lichens (Yahr et al., 2004). Cyanobacterial photobionts of L. pulmonaria do not seem to occur as free-living cyanobacterial strains, for example, indicating that their availability may be limited (Rikkinen et al., 2002). This 'photobiont limitation' might well be a mechanism leading to differential survival of dispersed ascospores of L. pulmonaria at various spatial scales (Werth et al. 2006a), which would be expected to

325 be reflected in the genetic structure of both the lichenised fungus and its photobionts. Coupled with a study on the photobiont-specificity of L. pulmonaria, a detailed community-level investigation of the availability of photobionts associated with L. pulmonaria should help to shed light on the importance of photobiont limitation.

Second, transplantation studies have shown that establishment rates of some endangered lichens propagating with vegetative propagules (soredia) are low (Zoller et al., 2000); this is also the case in L. pulmonaria (Scheidegger, 1995; Werth et al., 2006a). Werth et al. (2006a) observed substantial differences in survival rates of vegetative propagules among the investigated forest stands. Thus, the establishment of $L$. pulmonaria from soredia appears to be limited by unfavourable 335 environmental conditions (Werth et al., 2006a). Additionally, diaspores dispersed over long distances might experience reduced establishment if they are maladapted to the environment they have dispersed to. More detailed studies are, however, necessary to fully assess the importance of local adaptation as a factor influencing the establishment of L. pulmonaria. 


\section{References}

Armstrong RA (1987) Dispersal in a population of the lichen Hypogymnia physodes. Environmental and Experimental Botany 27, 357-363.

345 Armstrong RA (1994) Dispersal of soredia from individual soralia of the lichen Hypogymnia physodes (L.) Nyl. in a simple wind tunnel. Environmental and Experimental Botany 34, 39-45.

Bailey RH (1976) Ecological aspects of dispersal and establishment in lichens. In: Lichenology: Progress and problems (eds. Brown DH, Hawksworth DL, Bailey RH), pp. 215-247. Academic Press, London.

Barkman JJ (1958) Phytosociology and ecology of cryptogamic epiphytes: including a taxonomic survey and description of their vegetation units in Europe Gorcum, Assen.

Dettki H, Klintberg P, Esseen P-A (2000) Are epiphytic lichens in young forests limited by local dispersal? Ecoscience 7, 317-325.

Dixon P (2003) Vegan, a package of R functions for community ecology. Journal of Vegetation Science 14, 927-930.

Evanno G, Regnaut S, Goudet J (2005) Detecting the number of clusters of individuals using the software STRUCTURE: a simulation study. Molecular Ecology 14, 2611-2620.

Excoffier L, Laval G, Schneider S (2005) Arlequin ver. 3.0: An integrated software package for population genetics data analysis. . Evolutionary Bioinformatics Online 1, 47-50

Falush D, Stephens M, Pritchard J (2003) Inference of population structure using multilocus genotype data: linked loci and correlated allele frequencies. Genetics 164, 1567-1587.

Galloway DJ, Aptroot A (1995) Bipolar lichens: A review. Cryptogamic Botany 5, 184-191.

Hanski I, Gaggiotti O (2004) Ecology, genetics, and evolution of metapopulations Elsevier, London.

Hardy OJ, Vekemans X (1999) Isolation by distance in a continuous population: reconciliation between spatial autocorrelation analysis and population genetics models. Heredity 83, 145-154.

Hilmo O (2002) Growth and morphological response of old-forest lichens transplanted into a young and an old Picea abies forest. Ecography 25, 329-335.

Johansson P, Ehrlén J (2003) Influence of habitat quantity, quality and isolation on the distribution and abundance of two epiphytic lichens. Journal of Ecology 91, 213-221.

370 Kalwij JM, Wagner HH, Scheidegger C (2005) Effects of stand-level disturbances on the spatial distribution of a lichen indicator. Ecological Applications 15, 2015-2024.

Kirchhofer W (1995) Klimaatlas der Schweiz Bundesamt für Landestopographie, Bern.

Legendre P, Legendre L (1998) Numeric ecology Elsevier, Amsterdam.

Levins R (1969) Some demographic and genetic consequences of environmental heterogeneity for biological control. Bulletin of the Entomological Society of America 15, 237-240.

Lidén M, Pettersson M, Bergsten U, Lundmark T (2004) Artificial dispersal of endangered epiphytic lichens: a tool for conservation in boreal forest landscapes. Biological Conservation 118, 431442.

Lindblom L, Ekman S (2006) Genetic variation and population differentiation in the lichen-forming ascomycete Xanthoria parietina on the island Storfosna, central Norway. Molecular Ecology 15, 1545-1559.

Manly BFJ (1985) The statistics of natural selection Chapman and Hall, London.

Manni F, Guerard E, Heyer E (2004) Geographic patterns of (genetic, morphologic, linguistic) variation: how barriers can be detected by using Monmonier's algorithm. Human Biology 76, $173-190$. 
Mantel N (1967) The detection of disease clustering and a generalized regression approach. Cancer Research 27, 209-220.

Minch E (2001) MICROSAT version 1.5., URL: http://hpgl.stanford.edu/projects/microsat/microsat.html.

390 Mitchell EAD, van der Knaap WO, van Leeuwen JFN, Buttler A, Warner BG, Gobat JM (2001) The palaeoecological history of the Praz-Rodet bog (Swiss Jura) based on pollen, plant macrofossils and testate amoebae (Protozoa). Holocene 11, 65-80.

Monmonier MS (1973) Maximum-difference barriers - alternative numerical regionalization method. Geographical Analysis 5, 245-261.

395 Öckinger E, Niklasson M, Nilsson SG (2005) Is local distribution of the epiphytic lichen Lobaria pulmonaria limited by dispersal capacity or habitat quality? Biodiversity and Conservation $\mathbf{1 4}$, $759-773$.

Oksanen J (2005) Vegan: Community ecology package. R package version 1.6-7. URL: http://cc.oulu.fi/ jarioksa/.

400 Paradis E, Strimmer K, Claude J, Jobb G, Opgen-Rhein R, Dutheil J, Noel Y, Bolker B (2004) Ape: Analyses of phylogenetics and evolution. $R$ package version 1.4. URL: http://www.Rproject.org.

Pritchard J, Stephens M, Donnelly P (2000) Inference of population structure using multilocus genotype data. Genetics 155, 945-959.

405 R Development Core Team (2004) R: a language and environment for statistical computing, URL: http://www.R-project.org.

Radies DN, Coxson DS (2004) Macrolichen colonization on 120-140 year old Tsuga heterophylla in wet temperate rainforests of central-interior British Columbia: a comparison of lichen response to even-aged versus old-growth stand structures. Lichenologist 36, 235-247.

410 Reynolds J, Weir BS, Cockerham CC (1983) Estimation of the coancestry coefficient: basis for a shortterm genetic distance. Genetics 105, 767-779.

Rikkinen J, Oksanen I, Lohtander K (2002) Lichen guilds share related cyanobacterial symbionts. Science 297, 357.

$415 \quad$ Lichenologist 39, 69-82.

Rolstad J, Gjerde I, Storaunet KO, Rolstad E (2001) Epiphytic lichens in Norwegian coastal spruce forest: historic logging and present forest structure. Ecological Applications 11, 421-436.

Rose F (1992) Temperate forest management: its effects on bryophyte and lichen floras and habitats. In: Bryophytes and lichens in a changing environment (eds. Bates JW, Farmer AM), pp. 211-233.

$420 \quad$ Clarendon, Oxford.

Scheidegger C (1995) Early development of transplanted isidioid soredia of Lobaria pulmonaria in an endangered population. Lichenologist 27, 361-374.

Scheidegger C, Clerc P, Dietrich M, Frei M, Groner U, Keller C, Roth I, Stofer S, Vust M (2002) Rote Liste der gefährdeten Arten der Schweiz: Baum- und erdbewohnende Flechten BUWAL, Bern.

Scheidegger C, Goward T (2002) Monitoring lichens for conservation: Red Lists and conservation action plans. In: Monitoring with lichens - monitoring lichens (eds. Nimis PL, Scheidegger C, Wolseley PA), pp. 163-181. Kluwer, Dordrecht.

Scheidegger C, Walser JC (1998) Reintroduction and augmentation of populations of the endangered Lobaria pulmonaria: methods and concepts. In: Lobarion lichens as indicators of the primeval 

Phytosociological Centre, Kiev.

Sillett SC, McCune B, Peck JE, Rambo TR, Ruchty A (2000) Dispersal limitations of epiphytic lichens result in species dependent on old-growth forests. Ecological Applications 10, 789-799.

Sjögren P (2006) The development of pasture woodland in the southwest Swiss Jura Mountains over 2000 years, based on three adjacent peat profiles. Holocene 16, 210-223.

Slatkin M (1993) Isolation by distance in equilibrium and nonequilibrium populations. Evolution 47, 264-279.

Snäll T, Fogelqvist J, Ribeiro PJ, Lascoux M (2004) Spatial genetic structure in two congeneric epiphytes with different dispersal strategies analysed by three different methods. Molecular Ecology 13, 2109-2119.

Snäll T, Pennanen J, Kivistö L, Hanski I (2005) Modelling epiphyte metapopulation dynamics in a dynamic forest landscape. Oikos 109, 209-222.

Snäll T, Riberiro PJ, Rydin H (2003) Spatial occurrence and colonisations in patch-tracking metapopulations: local conditions versus dispersal. Oikos 103, 566-578.

445 Søchting U, Alstrup V (2002) Danish Lichen Checklist. Version 1. URL http://www.bi.ku.dk/lichens/dkchecklist/.

Thor G (1998) Red-listed lichens in Sweden: habitats, threats, protection, and indicator value in boreal coniferous forests. Biodiversity and Conservation 7, 59-72.

Tønsberg T, Gauslaa Y, Haugan R, Holien H, Timdal E (1996) The threatened macrolichens of Norway. Sommerfeltia 23, 1-258.

Wagner HH, Holderegger R, Werth S, Gugerli F, Hoebee SE, Scheidegger C (2005) Variogram analysis of the spatial genetic structure of continuous populations using multilocus microsatellite data. Genetics 169, 1739-1752.

Wagner HH, Werth S, Kalwij JM, Scheidegger C (2006) Modelling forest recolonization by an epiphytic lichen using a landscape genetic approach. Landscape Ecology 21, 849-865.

Walser JC (2004) Molecular evidence for limited dispersal of vegetative propagules in the epiphytic lichen Lobaria pulmonaria. American Journal of Botany 91, 1273-1276.

Walser JC, Gugerli F, Holderegger R, Kuonen D, Scheidegger C (2004) Recombination and clonal propagation in different populations of the lichen Lobaria pulmonaria. Heredity 93, 322-329.

460 Walser JC, Holderegger R, Gugerli F, Hoebee SE, Scheidegger C (2005) Microsatellites reveal regional population differentiation and isolation in Lobaria pulmonaria, an epiphytic lichen. Molecular Ecology 14, 457-467.

Walser JC, Zoller S, Büchler U, Scheidegger C (2001) Species-specific detection of Lobaria pulmonaria (lichenized ascomycete) diaspores in litter samples trapped in snow cover. Molecular Ecology 10, 2129-2138.

Werth S, Sork VL (submitted) Local genetic structure and host specificity in an epiphytic lichen. American Journal of Botany.

Werth S, Wagner HH, Gugerli F, Holderegger R, Csencsics D, Kalwij JM, Scheidegger C (2006a) Quantifying dispersal and establishment limitation in a population of an epiphytic lichen. Ecology 87, 2037-2046.

Werth S, Wagner HH, Holderegger R, Kalwij JM, Scheidegger C (2006b) Effect of disturbances on the genetic diversity of an old-forest associated lichen. Molecular Ecology 15, 911-921.

Wirth V (1999) Gefährdete Flechtenbiotope in Mitteleuropa. Natur und Museum 129, 12-21. 
Wirth V, Schöller H, Scholz P, Ernst G, Feuerer T, Gnüchtel A, Hauck M, Jacobsen P, John V, Litterski B (1996) Rote Liste der Flechten (Lichenes) der Bundesrepublik Deutschland. Schriftenreihe für Vegetationskunde 28, 307-368.

Wright S (1943) Isolation by distance. Genetics 28, 114-138.

Yahr R, Vilgalys R, DePriest PT (2004) Strong fungal specificity and selectivity for algal symbionts in Florida scrub Cladonia lichens. Molecular Ecology 13, 3367-3378.

480 Yeh FC, Boyle TJB (1997) Population genetic analysis of co-dominant and dominant markers and quantitative traits. Belgian Journal of Botany 129, 157.

Yoshimura I (1971) The genus Lobaria of Eastern Asia. Journal of the Hattori Botanical Laboratory 34, 231-364.

Zoller S, Frey B, Scheidegger C (2000) Juvenile development and diaspore survival in the threatened epiphytic lichen species Sticta fuliginosa, Leptogium saturninum and Menegazzia terebrata: Conclusions for in situ conservation. Plant Biology 2, 496-504.

\section{Acknowledgements}

$490 \quad$ We thank Delphine Grivet, Victoria L. Sork, Richard Abbott and several anonymous reviewers for providing valuable comments on this manuscript and Johanna Scheidegger for field assistance. This research is part of a project funded by the Swiss National Science Foundation (SNF) under the NCCR Plant Survival. This research was also funded by a post-doctoral fellowship to Silke Werth received from the Swiss National Science Foundation (PBBEA-111207).

495 Figure legends

Figure 1. Map of the study area in a Swiss pasture-woodland landscape showing proportions of ancestry defined from a Bayesian analysis of population structure (Pritchard et al., 2000) for Lobaria pulmonaria. Each pie chart shows the proportion of assignment of the L. pulmonaria samples from respective 1-ha plots to five populations $(K=5)$. Unassigned individuals had a probability $\leq 0.8$ of 500 belonging to either of the five populations. Grey: forests; white: wooded pastures. (Digital data from Landeskarte der Schweiz; (c) Bundesamt für Landestopographie, Berne).

Figure 2. Genetic discontinuities between plots of Lobaria pulmonaria from a Swiss pasture-woodland landscape. Based on 100 bootstrap replicates, barriers were drawn with line sizes proportional to their 505 bootstrap support. For barriers with high bootstrap values $(>50)$, the respective value is given. Dots show the locations of 1-ha plots, and the lines separating them from each other represent the Voronoi tessellation of the plots' coordinates (Manni et al., 2004). In the northwest of the study area, a significant barrier was found for three plots containing the same multilocus genotype. 


\section{Tables and Figures}

Table 1. Overview of the samples investigated in this study, showing plot ID (ID), the number of Lobaria pulmonaria thalli sampled in 1-ha plots (N), the number of host trees the lichen was sampled 515 from (Sampled), the number of hosts present in a plot (Hosts), the location of a plot either west or east of the large pasture separating forests of the study area (Area; see also Fig. 1), and the disturbance a plot was subjected to (Disturbance).

\begin{tabular}{lrrrll}
\hline ID & Hosts & Sampled & N & Area & Disturbance \\
\hline W009 & 9 & 8 & 22 & West & burnt \\
W014 & 4 & 4 & 23 & West & burnt \\
W015 & 1 & 1 & 4 & West & burnt \\
W021 & 2 & 2 & 24 & West & burnt \\
W036 & 4 & 4 & 23 & West & burnt \\
W037 & 2 & 2 & 15 & West & burnt \\
W046 & 7 & 7 & 21 & West & burnt \\
W061 & 2 & 1 & 23 & West & burnt \\
W071 & 6 & 5 & 22 & West & burnt \\
W079 & 10 & 7 & 24 & West & burnt \\
W093 & 5 & 5 & 28 & West & burnt \\
W098 & 23 & 21 & 41 & West & burnt \\
W103 & 5 & 2 & 12 & West & logged \\
W145 & 19 & 14 & 24 & West & logged \\
W151 & 104 & 22 & 22 & West & logged \\
W188 & 5 & 4 & 24 & West & logged \\
W226 & 15 & 9 & 21 & West & logged \\
W228 & 8 & 6 & 21 & West & logged \\
W229 & 20 & 12 & 17 & West & logged \\
W230 & 6 & 6 & 24 & West & logged \\
W238 & 9 & 6 & 23 & West & logged \\
W013 & 10 & 10 & 23 & East & uneven-aged \\
W032 & 2 & 2 & 22 & East & uneven-aged \\
W035 & 3 & 3 & 28 & East & uneven-aged \\
W043 & 5 & 4 & 24 & East & uneven-aged \\
W050 & 1 & 1 & 2 & East & uneven-aged \\
W082 & 12 & 8 & 24 & East & uneven-aged \\
W090 & 6 & 6 & 27 & East & uneven-aged \\
W096 & 5 & 5 & 26 & East & uneven-aged \\
W202 & 26 & 22 & 22 & East & uneven-aged \\
W040 & 4 & 4 & 24 & West & uneven-aged \\
W051 & 6 & 6 & 24 & West & uneven-aged \\
W052 & 1 & 1 & 3 & West & uneven-aged \\
W055 & 2 & 2 & 10 & West & uneven-aged \\
W064 & 6 & 5 & 29 & West & uneven-aged \\
W075 & 4 & 2 & 24 & West & uneven-aged
\end{tabular}




\begin{tabular}{lrrccc}
\hline ID & Hosts & Sampled & N & Area & Disturbance \\
\hline W089 & 2 & 2 & 24 & West & uneven-aged \\
W139 & 30 & 23 & 23 & West & uneven-aged \\
W185 & 34 & 25 & 26 & West & uneven-aged \\
W210 & 10 & 10 & 24 & West & uneven-aged \\
W221 & 11 & 9 & 22 & West & uneven-aged \\
\hline
\end{tabular}


525 Table 2. Ewens-Watterson tests for neutrality for six microsatellite loci of the lichen Lobaria pulmonaria, based on 889 samples. The statistics were calculated using 5000 simulated samples. Locus, name of microsatellite locus; n, number of thalli employed in the test; k, number of alleles; Obs.F, observed $F$-statistics; Mean.F, average value of the simulated $F$-statistics resulting; SE, standard error of simulated $F$-statistics; L95, lower $95 \%$ confidence interval of simulated $F$-statistics; U95,

530 upper $95 \%$ confidence interval of simulated $F$-statistics. A superscript of "ns" indicates that a particular locus does not deviate significantly from selective neutrality.

\begin{tabular}{lrrrrrrr}
\hline Locus & n & k & Obs.F & Mean.F & SE & L95 & U95 \\
\hline LPuO3 $^{\text {ns }}$ & 889 & 4 & 0.701 & 0.674 & 0.040 & 0.339 & 0.982 \\
LPuO9 $^{\text {ns }}$ & 889 & 20 & 0.272 & 0.215 & 0.006 & 0.114 & 0.428 \\
LPu15 $^{\text {ns }}$ & 889 & 16 & 0.236 & 0.264 & 0.011 & 0.135 & 0.545 \\
LPu16 $^{\text {ns }}$ & 889 & 13 & 0.223 & 0.316 & 0.015 & 0.157 & 0.646 \\
LPu2O $^{\text {ns }}$ & 889 & 28 & 0.101 & 0.155 & 0.003 & 0.087 & 0.303 \\
LPu27 $^{\text {ns }}$ & 889 & 6 & 0.511 & 0.544 & 0.035 & 0.266 & 0.930 \\
\hline
\end{tabular}


Table 3. Results of two analyses of molecular variance (AMOVA) of 37 plots nested within regions (plot 540 level) and of 153 trees nested within plots (tree level) for Lobaria pulmonaria in a Swiss pasturewoodland landscape. df: degrees of freedom; SS: sum of squares; Var: percentage of molecular variance; $\Phi$-statistics: fixation index. A superscript "ns" indicates that a respective variance component was not statistically significant $(\mathrm{p}>0.05)$. An asterisk indicates that a respective variance component is statistically significant at $\alpha=0.001 \%$. The overall $\Phi_{\mathrm{ST}}$ from the plot level analysis was $0.462^{*}$, and 545 from tree-level analysis was $0.817^{*}$.

\begin{tabular}{lrrrl}
\hline Source of variation & df & SS & Var & $\Phi$-statistics \\
\hline Plot level & & & & \\
$\quad$ Among regions & 1 & 5.5 & 0.0 & $\Phi_{\mathrm{CT}}=0.000^{\mathrm{ns}}$ \\
Among plots within regions & 35 & 180.8 & 46.5 & $\Phi_{\mathrm{SC}}=0.464^{*}$ \\
Within plots & 759 & 201.4 & 53.5 & \\
Tree level & & & & \\
$\quad$ Among plots & 37 & 178.3 & 32.2 & $\Phi_{\mathrm{CT}}=0.322^{*}$ \\
Among host trees within plots & 115 & 131.2 & 49.5 & $\Phi_{\mathrm{SC}}=0.730^{*}$ \\
Among thalli within host trees & 591 & 53.5 & 18.3 & \\
\hline
\end{tabular}




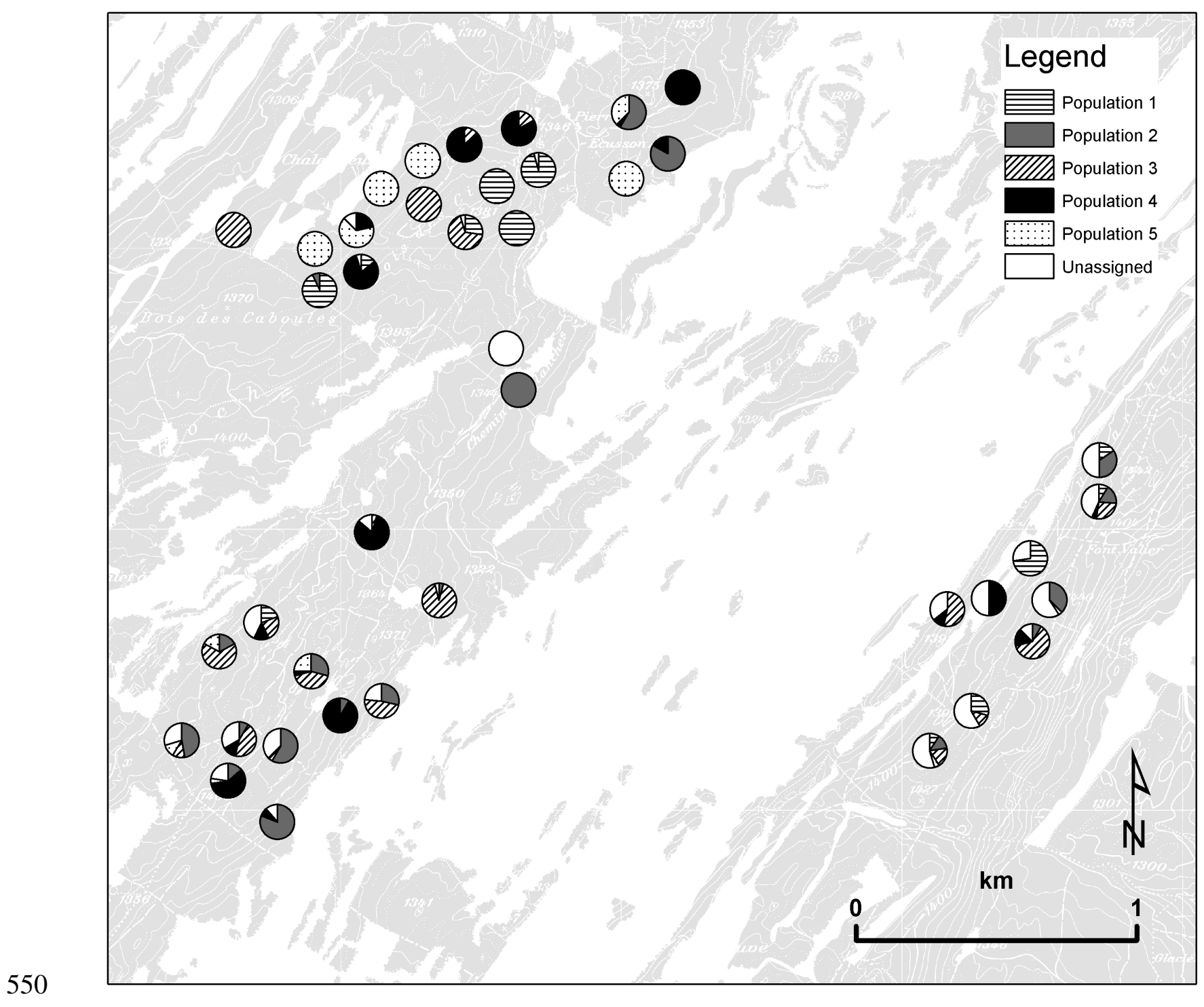

Figure 1 


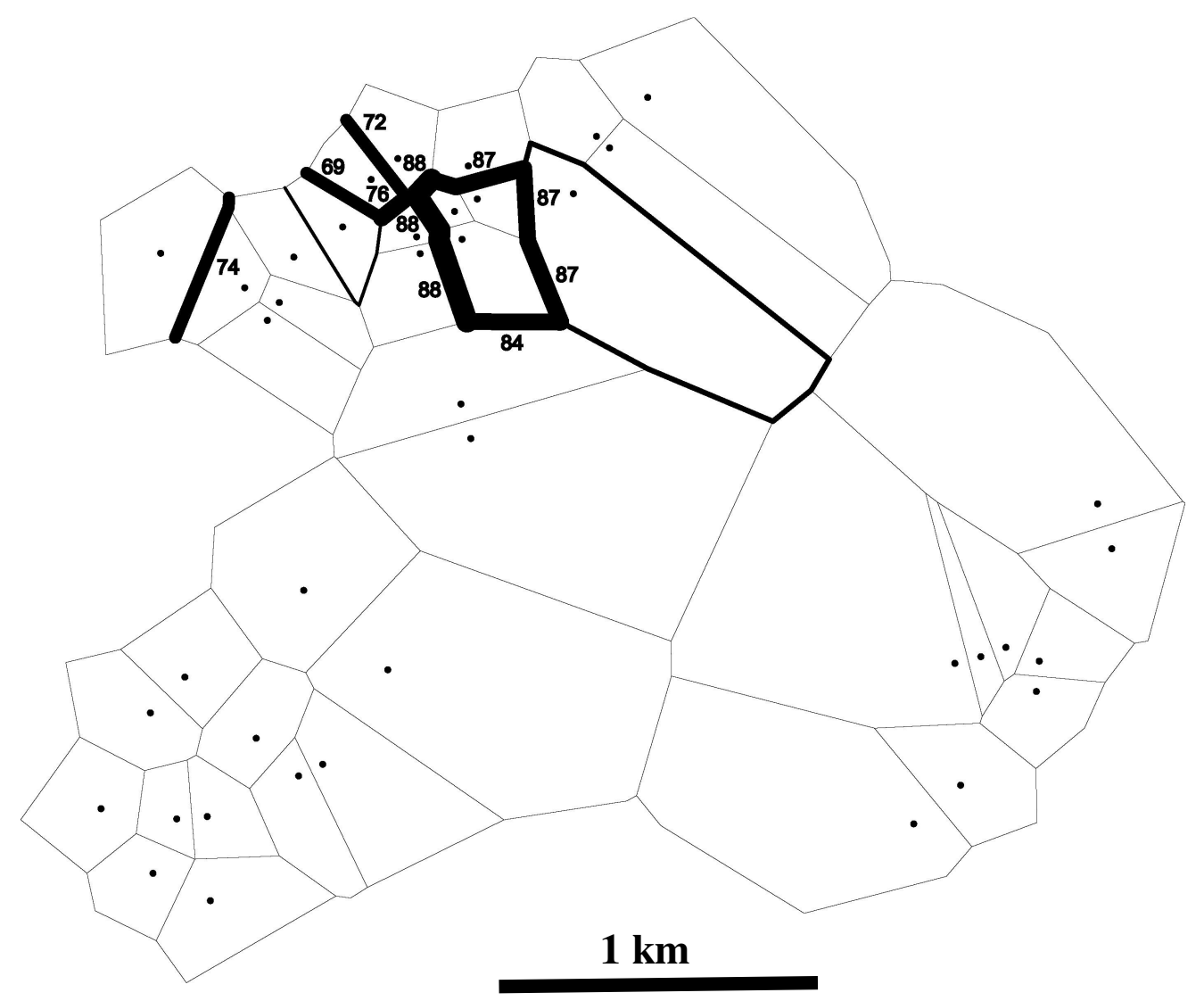

Figure 2 


\section{Author information box}

This work was part of Silke Werth's PhD research on gene flow and dispersal of lichenised fungi in a dynamic pasture-woodland landscape. She continues studying gene flow of lichens at the Department

565 of Ecology and Evolutionary Biology of the University of California at Los Angeles. Felix Gugerli's research focuses on the application of molecular markers for elucidating population processes in space and time. Rolf Holderegger investigates the population and landscape genetics of plants and animals and their application in conservation biology. Helene H. Wagner focuses on spatial analysis and modelling as applied in community ecology and landscape genetics. Daniela Csencsics studies the 570 population genetics of lichens and rare forest trees. Christoph Scheidegger's research interests cover the population genetics and conservation biology of lichenised fungi. 